\title{
LA-ICP MS Characteristic of Geochemical Composition of Veins Rocks from the Central Part of the Khibina Massive in Kola Peninsula, Northern Russia
}

\author{
Miłosz Huber ${ }^{*}$ \\ Optical and Electron Microscopy Laboratory, Geology and Litosphere Protection Departament, Earth Science and Spatial \\ Management Faculty, Maria Curie-Skłodowska University, Lublin 20-718, Poland
}

Received: November 30, 2013 / Accepted: December 18, 2013 / Published: April 25, 2014.

\begin{abstract}
This paper discusses the vein rocks located in the central part of Khibina Mts.. These rocks are located on the border of two zones: ore and external. In the ore, zone is present titanite-nepheline bodies whilst in the outer zone are massive-syenites "khibinites". The veins can be divided into: mikrosyenites, melteigites and other rock types (e.g., tinguaites). The results of LA-ICP MS (laser ablation of inductively coupled plasma mass spectrometry) indicate that these rocks are associated with deep zones which formed as a result of injection of primary magma and contamination of fluids during migration, where there have hydrothermal processes. Rock-forming minerals, their corrosion and accessory minerals indicate these processes, too.
\end{abstract}

Key words: Khibina Massive, Kola Peninsula, vein rocks, geochemistry.

\section{Introduction}

Khibina Massive is a central intrusion, located near the Imandra, Umboziero Gully Lakes, in the central part of Kola Peninsula on the northern part of Baltic Shield. These intrusion is late Devonian [1-5], surrounded by Archean migmatitic gneisses of Kola series and metasediments of Imandra-Varzuga complexes [6-8]. There is a multi zonal massive with characteristic, specific mineralization. In the central part is located an ore zone with titanite-apatite-nepheline bodies which accompanied alkaline syenites-khibinites from the occurrence zone. These syenites are massive rocks with grey color and visible alkali-feldspar with aegirinites (Fig. 1). In the contact of these zones, they are present a numerous mineral veins, represented by the tingualites, metleigites and microsyenites. These rocks are studied in the paper.

\footnotetext{
*Corresponding author: Miłosz Huber, Dr., research field: geological sciences. E-mail: mhuber@umcs.lublin.pl.
}

\section{Methods}

It was make the observation in the Malaya Belaya Valley near Ramzaya Pass and in other region at the Bolshoi Vudyavr Lake. The 150 samples were taken and make the microscopic observation used a polarysed cross and reflected light (Leica DM 2500P) and electron scanning microscope (Hitachi SU6600) with EDS (energy dispersive X-ray spectrometry). In selected samples was make the LA-ICP-MS (laser ablation inductively coupled plasma mass spectrometry) analysis (model ELAN DRC II, Perkin Elmer with laser microsonde (LA) LSX-500, of CETAC). The microscopic observation was made in the Optical and Electron Microscpy Laboratory in Geology and Litosphere Protection Department, Earth Science and Spatial Management Faculty at the Maria Curie-Sklodowska University in Lublin, whilst the LAICP was make in Environment Analytic Laboratory in Geochemistry and Environment Protection Faculty at the Jan Kochanowski University in Kielce, Poland. 


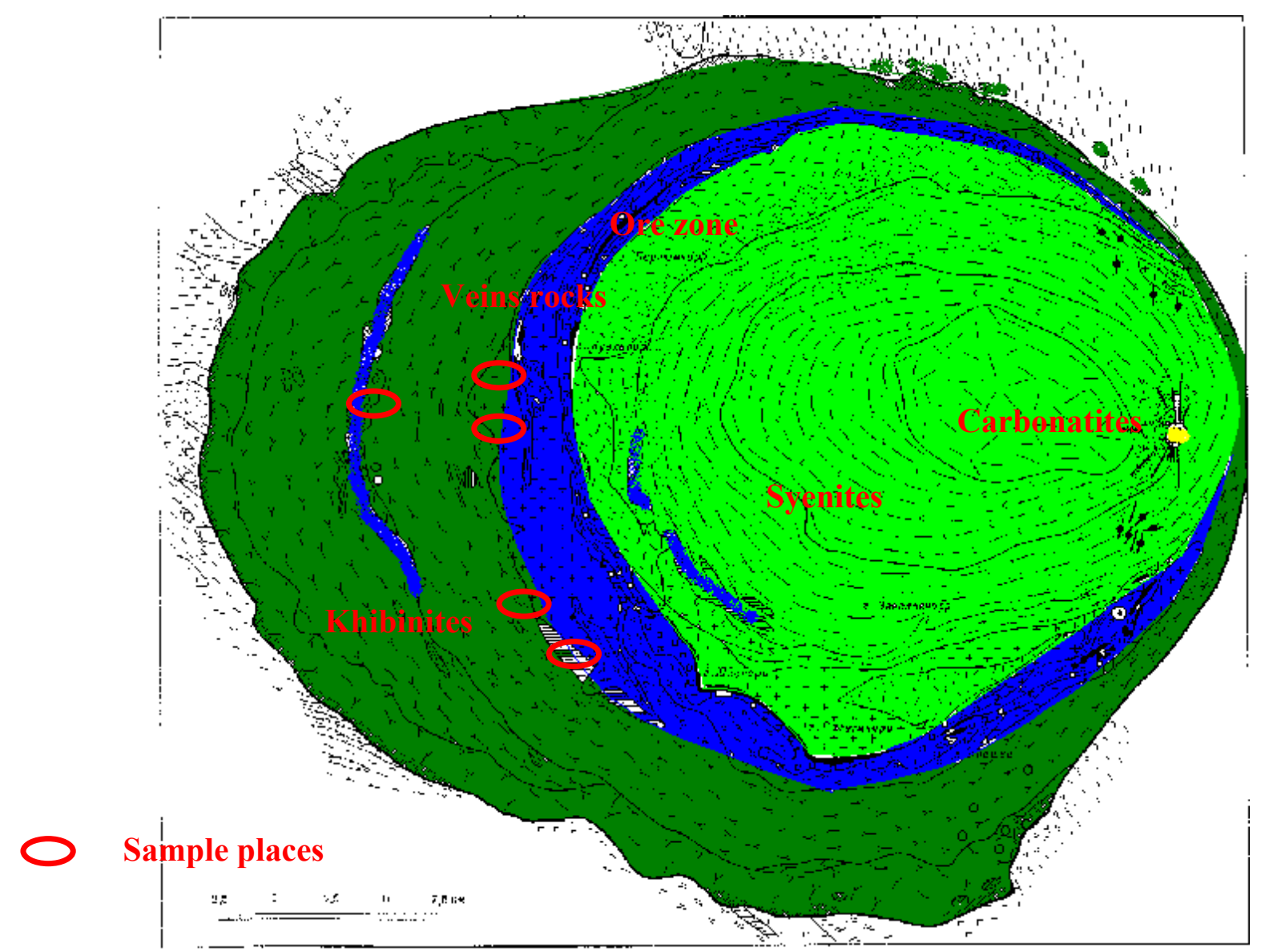

Fig. 1 Geology map of the Khibina Mts. with the samples localization.

\section{Results}

\subsection{Microscopic Observations}

In the occur of the veins, rocks are present massive syenites with a nepheline-aegirine urtites and apatite-nepheline ores. Massive syenites usually have large crystalline structure, dense, disordered texture, rare radiant and directional. Background of massive syenites form the automorphic nepheline crystals (up to $25 \%$ vol.), orthoclase (up to $24 \%$ vol.) and apatite (up to $15 \%$ vol.) among which are the needle of aegirine-acmite (up to $21 \%$ vol.), and xenomorphic crystals of eudialite (often with numerous inclusions these last crystals-to $15 \%$ vol.), plagioclases (acid varieties to $10 \%$ vol.). In these rocks, they are also subordinate to a maximum of $15 \%$ vol.: ilmenite, titanite, magnetite, arfvedsonite, riebeckite, astrophyllite, aenigmatite, lorenzenite and others (Fig. 2).
Nepheline-aegirine urtites are gery-black-grennish rocks with the visible on the background a nepheline crisstals with accompanied plagioclases, aegirines acmites with accesoric minerals. It has a large-crystalls, pseudotrahyte structure. The apatite-nepheline ores it are a green-brownish color (with red tint). There are massive rocks with nepheline crystalls and tytanitem with addition of apatite. In these massive syenites is present a numerous of mineral veins (Table 1) such as: tinguaites, melteigites and microsyenites.

Syenite veins have a massive texture, fine crystalline structures. These veins are the largest group of rocks. Form the veins of both a sharp contact and (often) those which have blurred boundaries are plastically deformed, with budinage structures. They are usually microsyenites (ijolites) with an increased amount of mafic minerals (up to $70 \%$ vol.), are rich in 

Khibina Massive in Kola Peninsula, Northern Russia

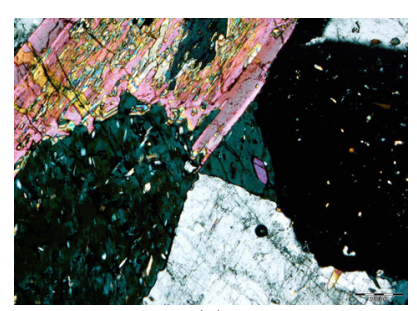

(a)

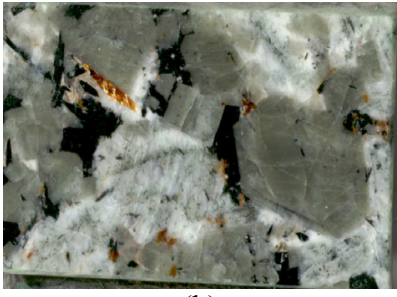

(b)

Khibinite rock ((a) thin section, crossed pollars; (b) the polished sample of rocks)

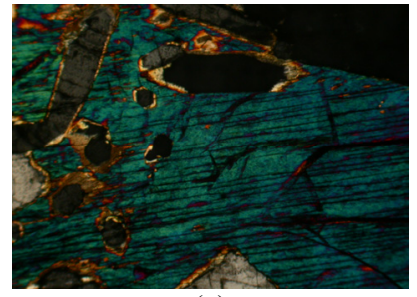

(c)

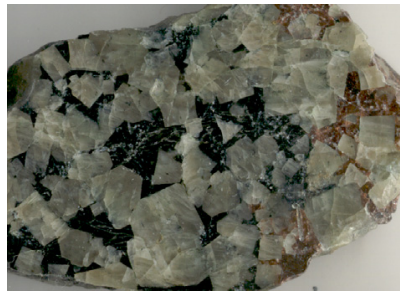

(d)

Urtite rock ((c) thin section, crossed pollars; (d) the polished sample of rocks)

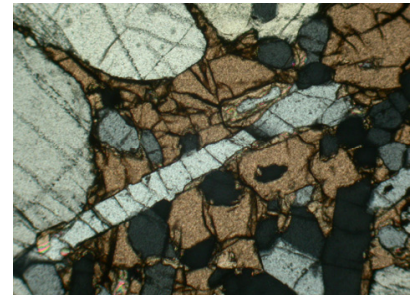

(e)

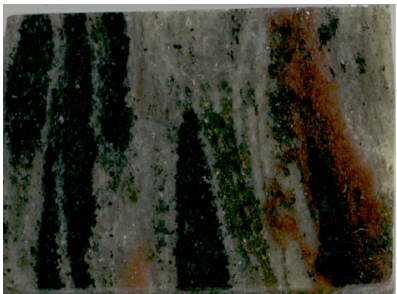

(f)

Titatnite-nepheline-apatite ore mineralization ((e) thin section, crossed pollars; (f) the polished sample of rocks)

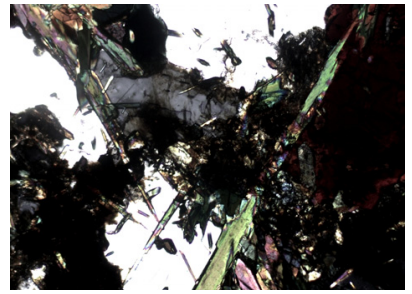

(g)

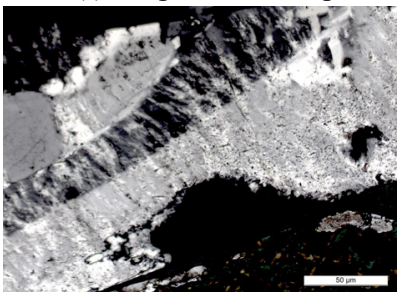

(h)

Microsyenite rocks (thin section, crossed pollars, sample: (g) 14CH02, (h) 19CH02)

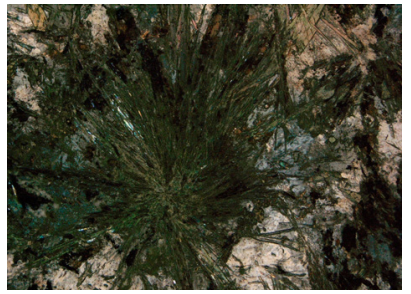

(i)

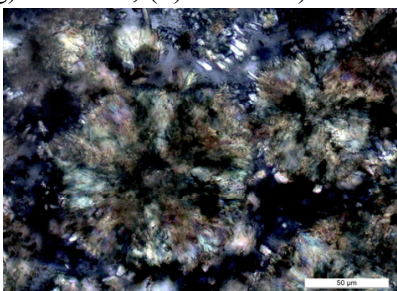

(j)

Tinguaite rocks (thin section, crossed pollars, sample: (i) $23 \mathrm{CH} 02$, (j) $02 \mathrm{CH} 10$ )

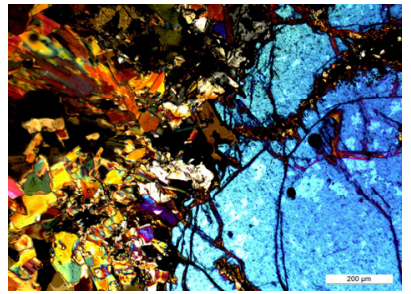

(k)

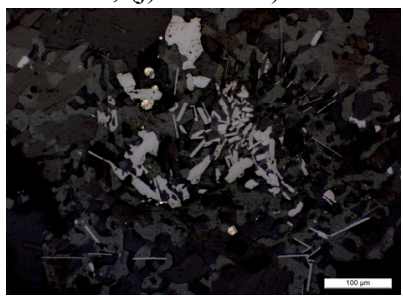

(1)

Melteigite rocks (thin section, crossed pollars, sample: (k) 08CH02, (1) 02CH03)

Fig. 2 Microphotographs of typical rocks from studied area. 
Table 1 Planimetric composition of studiem rocks.

\begin{tabular}{|c|c|c|c|c|c|c|}
\hline \multirow{2}{*}{ No. of sample } & \multicolumn{5}{|c|}{ Planimetric composition ( $\%$ obj.) } & \multirow{2}{*}{-Name of rock } \\
\hline & $\mathrm{Ne}$ & $\mathrm{K}-\mathrm{fs}$ & Pl & Dark & Others & \\
\hline 07CH02 & 25 & 24 & 5 & 30 & 15 (ap) & Foidic syenite (khibinite) \\
\hline 08CH02 & 3 & 7 & 4 & 69 & 7 (ol) 10 (ap) & Melteigite \\
\hline 10CH02 & 20 & 30 & 0 & 35 & 7 (ap) 8 (zr) & Foidic syenite (khibinite) \\
\hline 11CH02-II wyp. & 10 & 12 & 0 & 71 & 8 (ap) & Ijolite \\
\hline 11CH02-I wyp. & 7 & 41 & 9 & 39 & 4 (ap) & Foidic syenite (khibinite) \\
\hline $13 \mathrm{CH} 02$ & 24 & 10 & 0 & 37 & 17 (ap) 12 (zr) & Foidic syenite (khibinite) \\
\hline $14 \mathrm{CH} 02$ & 17 & 14 & 0 & 58 & 2 (ap) 9 (zr) & Ijolite \\
\hline $15 \mathrm{CH} 02$ & 2 & 55 & 0 & 34 & 9 (ap) & Fiodic mikrosyenite \\
\hline 16CH02-II wyp. & 13 & 16 & 0 & 71 & 0 & Foidic syenite (khibinite) \\
\hline 16CH02-I wyp. & 39 & 0 & 0 & 55 & 7 (ap) & Ijolite \\
\hline $17 \mathrm{CH} 02$ & 3 & 25 & 0 & 72 & 0 & Foidic syenite (khibinite) \\
\hline $18 \mathrm{CH} 02$ & 15 & 15 & 9 & 55 & 6 (ap) & Melteigite \\
\hline 19CH02-I wyp. & 13 & 57 & 0 & 27 & 4 (ap) & Foidic syenite (khibinite) \\
\hline 19СH02-II wyp. & 6 & 18 & 0 & 52 & 24 (ap) & Foidic syenite (khibinite) \\
\hline 20CH02 & 1 & 38 & 0 & 55 & 6 (ap) & Foidic syenite (khibinite) \\
\hline $21 \mathrm{CH} 02$ & 1 & 12 & 0 & 84 & 4 (ap) & Ijolite \\
\hline 22CH02-I wyp. & 3 & 20 & 3 & 28 & 48 (zr) & Foidic syenite (khibinite) \\
\hline 22CH02-II wyp. & 0 & 91 & 0 & 5 & 5 (ap) & Foidic syenite (khibinite) \\
\hline $23 \mathrm{CH} 02$ & 5 & 22 & 1 & 72 & 0 & Microsyenite-tinguaite \\
\hline $24 \mathrm{CH} 02$ & 11 & 20 & 0 & 45 & 11 (ap) 13 (zr) & Foidic syenite (khibinite) \\
\hline
\end{tabular}

ore minerals, mainly from the group of oxides of iron and titanium with admixtures of sulfides (including copper). Such melanocratic variety of syenite more often found in repeated vein fillings. The background are the crystalls of orthoclase rarely microclines (under to 55\% vol.), and aegirines (under 53\% vol.) with arfvedsonite (24\%), ith addition of apatite $(24 \%)$, nepheline (39\%), eudialite (do $48 \%$ obj), acid plagioclases (Ab, Lb, 9\% vol. of rocks), and ilmenite, titanite with sulphides (pyrite and chalkopyrite). The apatite is rich with strontium-calcium compounent. Near these minerals is present the inclusions of fluorite.

Tinguaites hale a beautifull grenish color, nematoblastic, fibroblastic structure, radial, dense texture. Matrix consists of radial concentrations of aegirine and astrophillite (up to $45 \%$ vol.). Near these minerals are orthoclase $(22 \%)$, nepheline $(5 \%)$, and titanite (up to $3 \%$ vol.). The rocks have also magnetite and ilmenite (up to $4 \%$ vol.). These minerals form narrow blades supporting aegirynes. These veins are most frequently met in the central part of Khibina. In the background of these rocks, they are present a radial conglomerates of aegirine with astrophyllites (under $45 \%$ vol.).

Melteigites there are veins have sharp contacts with host rocks. They have lepido-nemato-crystallic structures, massive, poikilite, porphyritic textures. Phenocrystalls of minerals are augite with addition of diopsides (to $24 \%$ vol.), and nodules, usually made up of olivine (rich in Fe, Fig. 4) with rims of Fe-biotite and phlogopite (Fig. 3). Matrix is composed of apatite (up to $10 \%$ vol.), nepheline (up to $15 \%$ vol.), orthoclase (up to $15 \%$ vol.) and plagioclase (up to $9 \%$ vol.). Less frequently rocks are pyroxenites occurring in what are called pyroxene (augite) suns (79\% vol.). In melteigites, pyroxene is sometimes characterized by structures such as radial augite sun. The presents pyrites have a small additin of $\mathrm{Ni}(0.5 \mathrm{wt} . \%)$ and $\mathrm{Cd}$ (0.2 wt. \%).

\subsection{LA-CP Analysis}

In the Tables 2 and 3, it is resent results of analysis 


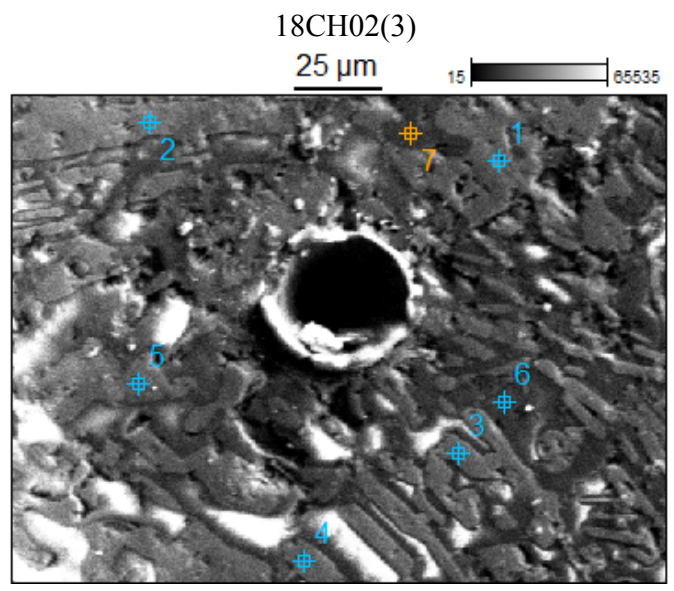

(a) The fotograph after La ICP analysis on theilmenite and augite.

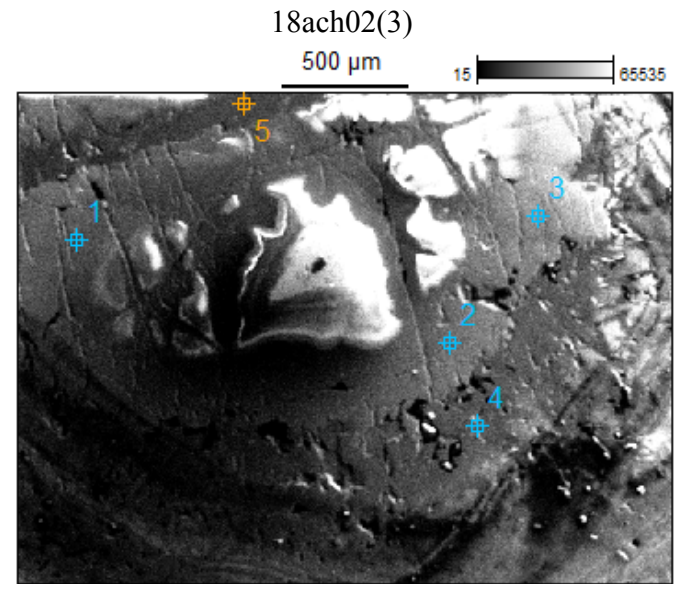

(b) Olywine with micas corona.

Fig. 3 Microphotographs from electron microscopy (SE) of samples rock.

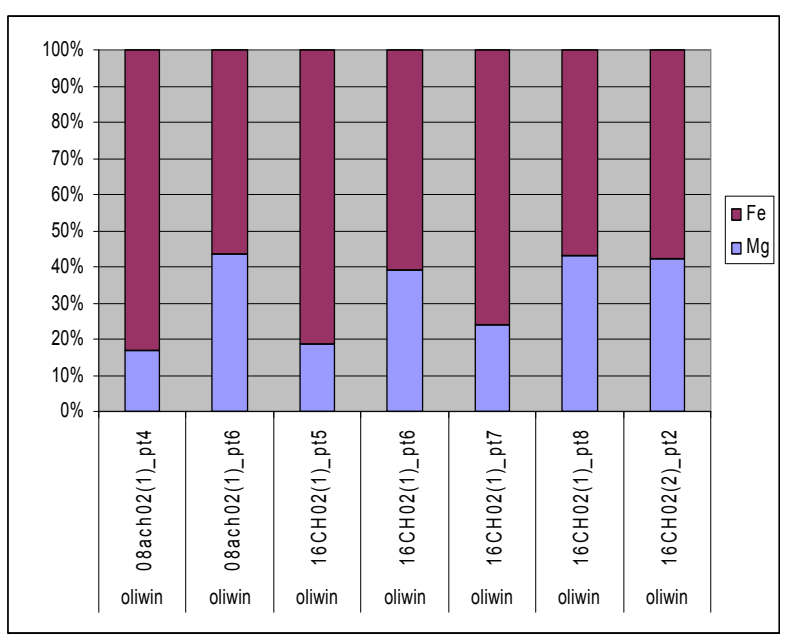

(a) Projection of olywine from the melteigite rocks.

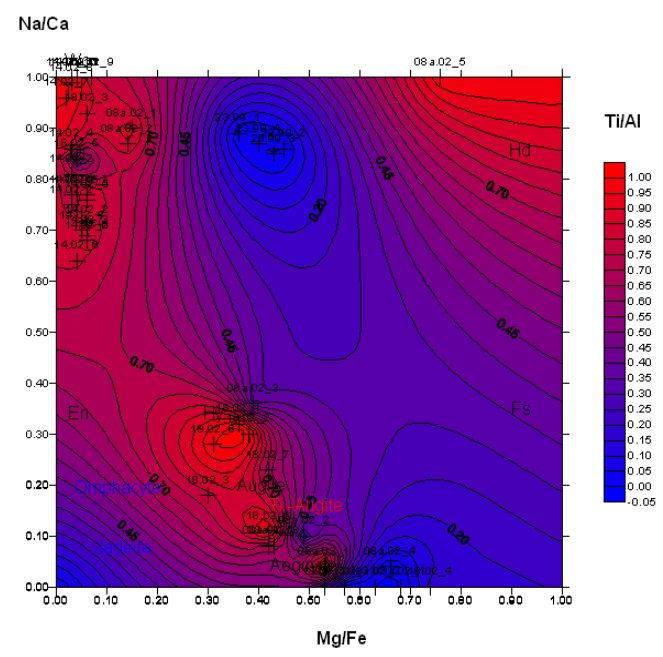

(b) Pyroxene projection from the analysed samples.

Fig. 4 EDS analysis of selected minerals.

Table 2 Chemical composition of rocks used by the LA-ICP-MS (reference material: polymetalic sulphide MASS-1, USGS).

\begin{tabular}{|c|c|c|c|c|c|c|c|c|}
\hline \multirow{2}{*}{ Sample } & $\mathrm{Pb}$ & $\mathrm{Cu}$ & As & $\mathrm{Zn}$ & $\mathrm{Cd}$ & $\mathrm{Ni}$ & Co & $\mathrm{Ag}$ \\
\hline & \multicolumn{8}{|c|}{$\mathrm{mg} / \mathrm{kg}(\mathrm{ppm})$} \\
\hline \multirow{4}{*}{$21 \mathrm{CH} 02$} & 15,508 & 3.3 & 24 & 208 & 23 & 84 & 11 & $<1$ \\
\hline & 15,827 & 31 & 35 & 101 & 30 & 30 & 6 & $<1$ \\
\hline & 15,744 & 33 & 2 & 233 & 25 & 10 & 5 & $<1$ \\
\hline & 15,867 & 37 & 32 & 218 & 24 & 231 & 25 & $<1$ \\
\hline \multirow{4}{*}{ 08CH02 } & 15,888 & 345 & 25 & 40 & 24 & 34 & 17 & $<1$ \\
\hline & 15,919 & 36 & 35 & 215 & 24 & 8 & 1 & $<1$ \\
\hline & 15,895 & 32 & 36 & 234 & 24 & 8 & 1 & $<1$ \\
\hline & 15,899 & 38 & 36 & 243 & 25 & 8 & 1 & $<1$ \\
\hline \multirow{3}{*}{ 14CH02 } & $<1$ & 2 & $<1$ & $<1$ & $<1$ & 2 & $<1$ & $<1$ \\
\hline & $<1$ & $<1$ & $<1$ & 24 & $<1$ & 2 & $<1$ & $<1$ \\
\hline & $<1$ & 2 & $<1$ & 30 & $<1$ & 2 & 3 & $<1$ \\
\hline \multirow{2}{*}{ 18CH02 } & $<1$ & 2 & $<1$ & 8 & $<1$ & 3 & $<1$ & $<1$ \\
\hline & $<1$ & 1 & $<1$ & 20 & $<1$ & 7 & 7 & $<1$ \\
\hline
\end{tabular}


Table 3 Chemical composition of rocks used by the LA-ICP-MS (reference material: REE element sof the glass matrix NIST 612).

\begin{tabular}{|c|c|c|c|c|c|c|c|c|c|}
\hline \multirow{2}{*}{ Sample } & $\mathrm{Pb}$ & $\mathrm{Cu}$ & $\mathrm{Ni}$ & $\mathrm{Co}$ & $\mathrm{Ag}$ & $\mathrm{Ti}$ & $\mathrm{Eu}$ & $\mathrm{Gd}$ & $\mathrm{Ce}$ \\
\hline & \multicolumn{9}{|c|}{$\mathrm{mg} / \mathrm{kg}(\mathrm{ppm})$} \\
\hline \multirow{4}{*}{$16 \mathrm{CH} 02$} & 3 & 1,420 & 13,029 & 1,103 & 15 & 316 & 1 & 2 & 28 \\
\hline & $<1$ & 26 & 37 & 7 & $<1$ & 199 & 13 & 25 & 771 \\
\hline & $<1$ & 8 & 16 & $<1$ & $<1$ & 95,207 & 1 & 4 & 131 \\
\hline & $<1$ & 16 & 19 & 25 & $<1$ & 4,434 & 3 & 9 & 91 \\
\hline \multirow{3}{*}{$15 \mathrm{CHCH}$} & 24 & 56 & 53 & 77 & 3 & 28,387 & 27 & 78 & 2,275 \\
\hline & 23 & 57 & 61 & 72 & $<1$ & 42,221 & 3 & 7 & 269 \\
\hline & 48 & 109 & 111 & 178 & 5 & 52,081 & $<1$ & 3 & 103 \\
\hline \multirow{6}{*}{$23 \mathrm{CH} 02$} & 3 & $<1$ & $<1$ & $<1$ & $<1$ & 246 & $<1$ & $<1$ & 1 \\
\hline & 3 & 2 & 2 & $<1$ & $<1$ & 240 & $<1$ & $<1$ & 4 \\
\hline & 2 & 312 & 696 & 2,341 & 2 & 871 & $<1$ & $<1$ & 6 \\
\hline & 3 & 36 & 9 & 23 & $<1$ & 640 & 1 & 1 & 48 \\
\hline & 4 & 2 & $<1$ & 1 & 1 & 214 & $<1$ & $<1$ & $<1$ \\
\hline & 3 & 36 & 7 & 4 & $<1$ & 153 & $<1$ & $<1$ & 4 \\
\hline
\end{tabular}

selected rock samples from the study area. In the veins samples is present a higher content of $\mathrm{Pb}$ and $\mathrm{Zn}$ (samples 21CH02 and 08CH02). In samples: 16CH02 and $15 \mathrm{CH} 03$ was measured a high contents of $\mathrm{Ti}, \mathrm{Ni}$ and $\mathrm{Ce}$.

\section{Conclusions}

Describe veins rocks from Khibina have advanced syenitization processes. The primitive mineral association has a corrosion in rocks veins. This was a product of mixed chemical composition of veins materials with occur rocks. The melteigite rock probably is a differenciation product in the intrusive magma and migration of basic derivates with contamination of syenite fluids. These fluids make unstable the ol-opx association (Figs. 3 and 4). In next step, a cpx minerals was crystallized which was make aegirinization (secondary processes). It can provide the numerous structures disintegrating, crowns reaction in olivine and pyroxene around, and relatively high content in the background a nepheline and feldspar. In addition, vein rocks fill the various discontinuities accompanying the transition zone which is undoubtedly limit ore occurrences and khibinites. This causes multistage migration of fluids in zones splits and enrichment rock core in the phase associated with the crystallization of residual and after-magmas processes [4]. Hence, are visible in the area of various multiple fill the same vein different generation and the presence of carbonate minerals found in many rocks in Khibina [3, 9, 10] and the enrichment of these rocks in the elements cerium group. In addition, the activity associated with hydrothermal after-magmas processes involves the enrichment of these rocks $\mathrm{Zn}-\mathrm{Pb}$ sulphides and minerals, for example, fluorite.

\section{Acknowledgments}

Special thanks to Professor Agnieszka Gałuszka from the Jan Kochanowski University in Kielce for making the analyses using the LA-ICP-MS technique of selected rocks samples.

\section{References}

[1] Borucky, B. E. Rock-Forming Minerals of High-alkaline Complexes; Nauka, 1989; p 214.

[2] Kogarko, L. N.; Kononova, V. A.; Orlova, M. P.; Woolley, A. R. Alkaline Rocks and Carbonatites of the World. Part 2: Former USSR; Chapman\&Hall: London, 1995; p 226.

[3] Kramm, U.; Kogarko, L. N.; Kononova, V. A.; Vartiainen, H. The Kola Alkaline Province of the CIS and Finland: Precise Rb-Sr Ages Define 380-360 Ma Age Range for All Magmatism. Lithos. 1993, 30, 33-44.

[4] Huber, M. Preliminary Characterization of the Mineral Veins Occurring in the Malaya Belaya Valley in the Khibiny. J. Biol. Earth Sci. 2013, 3(1), E1-E11. 

Khibina Massive in Kola Peninsula, Northern Russia

[5] Pozhylienko, W. I. Geology of Mineral Areas in Murmansk Region; Apatity, 2002; p 360.

[6] Arzamastsev, A. A. Unique Paleozoic Intrusions of the Kola Peninsula; Apatity: Kola Scientific Centra, 1994; p 79.

[7] Arzamastsev, A.; Yakovenchuk, V.; Pakhomovsky, Y.; Ivanyuk, G. The Khibina and Lovozero Alkaline Massifs: Geology and Unique Mineralization. 33 IGC Excursion Materials 2008.

[8] Mitrofanov, A. F. Geological Characteristics of Kola
Peninsula; Russian Academy of Science: Apatity, 2000; p 166.

[9] Huber, M.; Hałas, S.; Sikorska, M. Evolution of Prehnite-Albite-Calcite Veins in Metamorphic Rocks from the Lapland Granulite Belt (Kandalaksha Region of Kola Peninsula). Geologija 2007, 57, 1-7.

[10] Hałas, S.; Huber, M.; Piestrzynski, A. Petrology of Gabbroides and Isotope Signature of Sulfide Mineralization from Fedorov-Pansky Layered Mafic Intrusion. Geochronometria 2009, 33, 19-22. 